\title{
RESEARCH IN THE HISTORY OF
}

ECONOMIC THOUGHT AND METHODOLOGY: INCLUDING A SYMPOSIUM ON BRUCE

CALDWELL'S BEYOND POSITIVISM AFTER 35 YEARS 


\section{RESEARCH IN THE HISTORY OF ECONOMIC THOUGHT AND METHODOLOGY}

Founding Editor: Warren J. Samuels (1933-2011)

Series Editors: Luca Fiorito, Scott Scheall, and Carlos Eduardo Suprinyak

Recent Volumes:

Volume 31B: Research in the History of Economic Thought and Methodology: Documents Related to John Maynard Keynes, Institutionalism at Chicago \& Frank H. Knight; Ross B.

Emmett; 2013

Volume 32: $\quad$ Research in the History of Economic Thought and Methodology: A Research Annual; Luca Fiorito; 2014

Volume 33: Research in the History of Economic Thought and Methodology: A Research Annual; Luca Fiorito, Scott Scheall, Carlos Eduardo Suprinyak; 2015

Volume 34A: Research in the History of Economic Thought and Methodology: Including a Symposium on Austrian Economics in the Postwar Era; Luca Fiorito, Scott Scheall, Carlos Eduardo Suprinyak; 2016

Volume 34B: Research in the History of Economic Thought and Methodology: Including a Symposium on Albert O. Hirschman; Luca Fiorito, Scott Scheall, Carlos Eduardo Suprinyak; 2016

Volume 35A: Research in the History of Economic Thought and Methodology: Including a Symposium on the Historical Epistemology of Economics; Luca Fiorito, Scott Scheall, Carlos Eduardo Suprinyak; 2017

Volume 35B: Research in the History of Economic Thought and Methodology: Including a Symposium on New Directions in Sraffa Scholarship; Luca Fiorito, Scott Scheall, Carlos Eduardo Suprinyak; 2017 
RESEARCH IN THE HISTORY OF ECONOMIC THOUGHT AND METHODOLOGY VOLUME 36A

\title{
RESEARCH IN THE HISTORY OF ECONOMIC THOUGHT AND METHODOLOGY: INCLUDING A SYMPOSIUM ON BRUCE CALDWELL'S BEYOND POSITIVISM AFTER 35 YEARS
}

\author{
EDITED BY \\ LUCA FIORITO
}

University of Palermo, Palermo, Italy

SCOTT SCHEALL

Arizona State University Polytechnic Campus, Mesa, AZ, USA

\section{CARLOS EDUARDO SUPRINYAK}

Universidade Federal de Minas Gerais, Belo Horizonte, Brazil

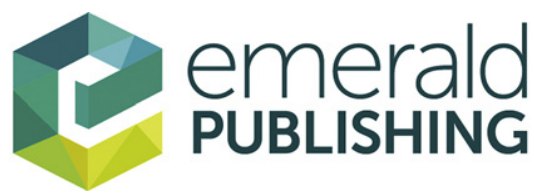

United Kingdom - North America - Japan India - Malaysia - China 
Emerald Publishing Limited

Howard House, Wagon Lane, Bingley BD16 1WA, UK

First edition 2018

Copyright (C) 2018 Emerald Publishing Limited

Reprints and permissions service

Contact: permissions@emeraldinsight.com

No part of this book may be reproduced, stored in a retrieval system, transmitted in any form or by any means electronic, mechanical, photocopying, recording or otherwise without either the prior written permission of the publisher or a licence permitting restricted copying issued in the UK by The Copyright Licensing Agency and in the USA by The Copyright Clearance Center. Any opinions expressed in the chapters are those of the authors. Whilst Emerald makes every effort to ensure the quality and accuracy of its content, Emerald makes no representation implied or otherwise, as to the chapters' suitability and application and disclaims any warranties, express or implied, to their use.

\section{British Library Cataloguing in Publication Data}

A catalogue record for this book is available from the British Library

ISBN: 978-1-78756-126-7 (Print)

ISBN: 978-1-78756-125-0 (Online)

ISBN: 978-1-78756-127-4 (Epub)

ISSN: 0743-4154 (Series) 


\section{CONTENTS}

LIST OF CONTRIBUTORS vii

EDITORIAL BOARD ix

ABOUT THE EDITORS $x i$

VOLUME INTRODUCTION xiii

\section{PART I}

A SYMPOSIUM ON BRUCE CALDWELL'S BEYOND POSITIVISM AFTER 35 YEARS

INTRODUCTION TO A SYMPOSIUM ON BRUCE

CALDWELL'S BEYOND POSITIVISM AFTER 35 YEARS Scott Scheall

A COUNTERCULTURAL METHODOLOGY:

CALDWELL'S BEYOND POSITIVISM AT THIRTY-FIVE Kevin D. Hoover

BEYOND DEDUCTIVISM

Tony Lawson

HYPOTHETICAL PATTERN EXPLANATIONS IN ECONOMIC SCIENCE: HAYEK'S EXPLANATION OF THE PRINCIPLE AND PATTERN PREDICTION MEETS CONTEMPORARY PHILOSOPHY OF SCIENCE

D. Wade Hands

WHY METHODOLOGY MATTERS: REFLECTIONS ON BRUCE CALDWELL'S BEYOND POSITIVISM

Peter Boettke, Solomon Stein and Virgil Henry Storr 
REFLECTING ON BEYOND POSITIVISM AT

THIRTY-FIVE

Bruce Caldwell

\section{PART II}

ESSAYS

RECENT TRENDS IN ECONOMIC METHODOLOGY:

A LITERATURE REVIEW

Luis Mireles-Flores

WHY IS “STIGLER'S COASE THEOREM" STIGLERIAN?

A METHODOLOGICAL EXPLANATION

Alain Marciano

\section{PART III}

FROM THE VAULT

JOHN M. CLARK AND FRANK H. KNIGHT ON

THE ADDING-UP THEOREM, OVERHEAD COSTS,

AND MORE

Luca Fiorito

INDEX 


\section{LIST OF CONTRIBUTORS}

Peter Boettke

Bruce Caldwell

Luca Fiorito

D. Wade Hands

Kevin D. Hoover

Tony Lawson

Alain Marciano

Luis Mireles-Flores

Scott Scheall

Solomon Stein

Virgil Henry Storr

Carlos Eduardo

Suprinyak
George Mason University, Fairfax, VA, USA

Duke University, Durham, NC, USA

University of Palermo, Palermo, Italy

University of Puget Sound, Tacoma, WA, USA

Duke University, Durham, NC, USA

Cambridge University, Cambridge, England, UK

MRE, Université de Montpellier, Montpellier, France

TINT, Social and Moral Philosophy, Department of Political and Economic Studies, University of Helsinki, Helsinki, Finland

Arizona State University Polytechnic Campus, Mesa, AZ, USA

George Mason University, Fairfax, VA, USA George Mason University, Fairfax, VA, USA Universidade Federal de Minas Gerais, Belo Horizonte, Brazil 


\section{EDITORIAL BOARD}

Michele Alacevich

University of Bologna, Italy

Rebeca Gomez Betancourt

University of Lumière Lyon 2,

France

John Davis

Marquette University, USA;

University of Amsterdam,

The Netherlands

Pedro Garcia Duarte

University of São Paulo, Brazil

Till Düppe

Université du Québec à Montréal, Canada

Ross Emmett

Arizona State University, USA
Mary Furner

University of California Santa

Barbara, USA

Nicola Giocoli

University of Pisa, Italy

Harald Hagemann

University of Hohenheim, Germany

Kyu Sang Lee

Ajou University, South Korea

Tiago Mata

University College, London, UK

Steven Medema

University of Colorado Denver, USA

Maria Pia Paganelli

Trinity University, USA 


\section{ABOUT THE EDITORS}

Luca Fiorito received his PhD in Economics from the New School for Social Research in New York and is currently an associate professor at the University of Palermo. His main area of interest is the history of American economic thought in the Progressive Era and the interwar years. He has published many works on the contributions of the institutionalists and on the relationship between economics and eugenics.

Scott Scheall is a Lecturer with Arizona State University's College of Integrative Sciences and Arts. He received his $\mathrm{PhD}$ in Philosophy from Arizona State in 2012. Scott is a former research fellow with Duke University's Center for the History of Political Economy and a former postdoctoral fellow with the F.A. Hayek Program for Advanced Study in Philosophy, Politics, and Economics at George Mason University. He has published extensively on the history and methodology of the Austrian School of economics.

Carlos Eduardo Suprinyak is Associate Professor of Economics at the Federal University of Minas Gerais (UFMG), Brazil. He specializes in the history of economic thought and economic methodology, studying in particular the interplay between social, political, and economic ideas in early modern England, and the institutionalization of academic economics in Brazil during the postwar era. He has published several papers on these and other related themes in peerreviewed scholarly journals, and is also the coeditor of The Political Economy of Latin American Independence (Routledge, 2017). 


\section{VOLUME INTRODUCTION}

We are delighted to present Volume 36A of Research in the History of Economic Thought and Methodology, the first of three volumes planned for 2018. The centerpiece of the volume is a symposium on the impact after 35 years of Beyond Positivism, Bruce Caldwell's influential 1982 book on economic methodology. The symposium features several significant contributors to the methodological literature of the past four decades, including Kevin Hoover, Wade Hands, Tony Lawson, and Peter Boettke. Professor Caldwell responds.

Our general-research section includes a review of recent methodological literature by Luis Mireles-Flores as well as Alain Marciano's methodological account of the Stiglerian nature of "Stigler's Coase Theorem."

Last, RHETM coeditor Luca Fiorito offers an archival piece culled from the papers of Frank Knight and John Maurice Clark that sheds light on several matters, including their published controversy concerning the significance of the so-called adding-up theorem.

Luca Fiorito

Scott Scheall

Carlos Eduardo Suprinyak

Editors 